\title{
Enhancing Groundwater Governance by Making the Linkage with Multiple Uses of the Subsurface Space and Other Subsurface Resources
}

\author{
Jac van der Gun ${ }^{1, *}$, Alice Aureli ${ }^{2}$ and Andrea Merla ${ }^{3}$ \\ 1 Consultant, Ganzeboomsweg 3 C, Schalkhaar 7433ES, The Netherlands \\ 2 UNESCO International Hydrological Programme (UNESCO-IHP), 7, place Fontenoy, Paris 07 SP 75352 , \\ France; a.aureli@unesco.org \\ 3 Consultant, Via Ponte dei Galli 2, Assisi 06081, Italy; merla.andrea@gmail.org \\ * Correspondence: j.vandergun@home.nl; Tel.: +31-570-854-611
}

Academic Editors: Sharon B. Megdal, Susanna Eden and Eylon Shamir

Received: 18 February 2016; Accepted: 17 May 2016; Published: 25 May 2016

\begin{abstract}
One of the aspects highlighted in the Framework for Action and other key documents produced by the Groundwater Governance Project (funded by GEF and implemented by UNESCO, FAO, World Bank and IAH) is the interdependence between groundwater and human activities related to other physical components of the real world. Consequently, it is important in groundwater governance to make essential linkages with other components of the water cycle (IWRM), with sanitation and wastewater management, with land use and land use practices, with energy and with the uses of subsurface space and other subsurface resources. This paper presents an overall description of the multiple uses of the subsurface space and of the exploitation and management of subsurface resources. It attempts to give an impression of intensities and trends in use and exploitation, of the possible interactions and of current and potential efforts to control negative impacts of such interactions. It concludes by briefly summarizing in three simple steps how to improve groundwater governance by making appropriate linkages with uses of the subsurface space and subsurface resources.
\end{abstract}

Keywords: groundwater governance; linkages; use of subsurface space; use of subsurface resources

\section{Introduction}

Groundwater governance is a complex concept that can be viewed from different angles. Hence, several definitions have been proposed, each with its own merits. We present here a definition adopted during the final stage of the Groundwater Governance Project, funded by GEF and implemented by UNESCO, FAO, World Bank and IAH:

"Groundwater governance comprises the promotion of responsible collective action to ensure socially-sustainable utilisation, control and protection of groundwater resources for the benefit of humankind and dependent ecosystems" [1]

This definition refers implicitly to the main components of groundwater governance: (1) actors; (2) information on the groundwater resources and their beneficial use; (3) a vision on goals to be pursued regarding groundwater and on how to achieve them (policy and planning); and (4) tools for regulation, control and protection (laws, regulations, incentives, etc.).

"Collective action" implies the existence of several actors that have to cooperate unisono in order to achieve the goals set. In relation to groundwater there is a large diversity of actors (governmental organizations, non-governmental organizations, research institutes, the private sector, individual 
citizens) who may act at different levels (ranging from local to national, and in some cases even supra-national levels). Many of these actors focus explicitly on groundwater, in their endeavors for using, draining, augmenting or protecting it, while the activities of many others address something else, but, at the same time, cause unintended impacts on groundwater ('side effects'). It goes without saying that information on and knowledge of the local groundwater systems and their state and context is indispensable for making informed decisions on groundwater. In many cases, however, there is much to be desired in this respect, with the result of considerable uncertainty: on current conditions and even more on how the future will look, either with or without the implementation of measures for control and protection. However, inadequate information is not the only reason for poor groundwater policies, planning and management. A myopic view may be another reason. Groundwater is not an isolated part of the world, but it is interacting with its surroundings, e.g., with surface water, with sanitation and with waste and wastewater management, with land use and land use practices, with energy and with the use of subsurface space and subsurface resources. Good governance requires that essential linkages are made, tailor-made to each particular case.

This paper focuses on only one of the mentioned categories of interactions: that between groundwater and the uses of the subsurface space and other subsurface resources. These uses will be briefly reviewed, while paying attention to their possible interaction with groundwater and to current and potential efforts to control negative impacts of such interactions. This may contribute to enhanced awareness of these interactions and to being alert to taking them duly into account in policies, planning and operational groundwater management. This is followed by a few suggestions on how to make these linkages in practice. The paper relies to a large extent on the outcomes of the Groundwater Governance Project, in particular on Thematic Paper No. 10 [2].

\section{Panorama of the Multiple Uses of the Subsurface Space and Subsurface Resources}

The most common human activities that take place in the subsurface are listed in Table 1. They fall into two main categories: (a) extraction of natural resources (water, energy, minerals, building materials, etc.) and (b) use of the underground space (for construction, transport and temporal or permanent storage of substances). Shallow groundwater abstraction and some forms of mining have been practiced already from time immemorial. Many other activities started only in more recent times. In general, one may say that human activities are nowadays encroaching rapidly into the subsurface, especially in densely populated areas, where the demand for natural resources is high and space is becoming scarce. These are the areas where conflicts between the different uses of the subsurface space and of its resources are most likely to occur.

Table 1. Main subsurface human activities.

\begin{tabular}{|c|c|c|}
\hline Category & Type of Activity & Geographic Distribution \\
\hline \multirow{3}{*}{$\begin{array}{l}\text { 1. Groundwater } \\
\text { development and } \\
\text { management }\end{array}$} & $\begin{array}{l}\text { Groundwater withdrawal for } \\
\text { different uses }\end{array}$ & $\begin{array}{l}\text { Widespread across the globe (withdrawal is } \\
\text { still rare at greater depths, beyond } 600 \mathrm{~m} \text { ) }\end{array}$ \\
\hline & $\begin{array}{l}\text { Drainage of excess } \\
\text { shallow groundwater }\end{array}$ & $\begin{array}{l}\text { In selected flat areas, mostly lowlands (USA, } \\
\text { Europe, China, Pakistan, India, Mexico) }\end{array}$ \\
\hline & Managed aquifer recharge & $\begin{array}{c}\text { Mostly in water-scarce areas, and in } \\
\text { coastal zones (to counterbalance } \\
\text { seawater intrusion) }\end{array}$ \\
\hline 2. Mining & $\begin{array}{l}\text { Extraction of minerals, coal, lignite, } \\
\text { building materials, etc. }\end{array}$ & $\begin{array}{l}\text { Scattered over the globe (where such } \\
\text { profitable resources have been identified) }\end{array}$ \\
\hline \multirow{3}{*}{$\begin{array}{l}\text { 3. Geo-energy } \\
\text { development (fluids as } \\
\text { carrier of energy) }\end{array}$} & Oil and gas development & In major geological basins on- and off-shore \\
\hline & $\begin{array}{l}\text { High-enthalpy geothermal } \\
\text { energy development * }\end{array}$ & $\begin{array}{c}\text { Areas of favorable temperature anomalies } \\
\text { (e.g., in USA, Japan, Iceland, Italy, Central } \\
\text { America, Indonesia, Philippines, Kenya, } \\
\text { China (Tibet), etc.) }\end{array}$ \\
\hline & $\begin{array}{l}\text { Low-enthalpy geothermal } \\
\text { resources development* }\end{array}$ & $\begin{array}{c}\text { Major sedimentary basins (e.g., France, } \\
\text { Germany, Brazil, etc.) }\end{array}$ \\
\hline
\end{tabular}


Table 1. Cont.

\begin{tabular}{|c|c|c|}
\hline Category & Type of Activity & Geographic Distribution \\
\hline \multirow{4}{*}{$\begin{array}{l}\text { 4. Disposal and storage } \\
\text { of hazardous waste }\end{array}$} & Waste disposal by deep well injection & $\begin{array}{l}\text { Often associated with mining, or with the } \\
\text { oil and gas industry }\end{array}$ \\
\hline & Carbon capture and sequestration & $\begin{array}{c}\text { Major projects in the North Sea, in Canada } \\
\text { and in Algeria }\end{array}$ \\
\hline & Subsurface storage of radioactive waste & $\begin{array}{l}\text { Mainly in selected countries, e.g., USA, } \\
\text { France, Russia, Japan and India }\end{array}$ \\
\hline & $\begin{array}{l}\text { Nuclear weapons testing and nuclear } \\
\text { power accidents }\end{array}$ & $\begin{array}{l}\text { e.g., in Western USA and French Polynesia } \\
\text { (tests); Russia and Japan (accidents) }\end{array}$ \\
\hline \multirow{5}{*}{ 5. Injection and recovery } & $\begin{array}{c}\text { Solution mining (e.g., using acids and } \\
\text { other lixiviants) }\end{array}$ & In selected mining areas \\
\hline & Injecting residual geothermal fluids & In geothermal energy development areas \\
\hline & Temporary storage of heat & Summer heat surplus used during winter \\
\hline & $\begin{array}{l}\text { Storage of hydrocarbons and fluids } \\
\text { associated with oil and natural } \\
\text { gas production }\end{array}$ & In or near oil and gas production areas \\
\hline & Hydraulic fracturing or "fracking" & $\begin{array}{l}\text { In zones where shale gas is explored } \\
\text { or exploited }\end{array}$ \\
\hline \multirow{3}{*}{$\begin{array}{l}\text { 6. Construction into the } \\
\text { underground space }\end{array}$} & Pipelines, sewerage systems and cables & $\begin{array}{l}\text { Very general around the world, in } \\
\text { particular in developed countries }\end{array}$ \\
\hline & Tunnels and underground railways & $\begin{array}{l}\text { In particular in many urban centers around } \\
\text { the world }\end{array}$ \\
\hline & $\begin{array}{l}\text { Underground car parks and other } \\
\text { underground constructions }\end{array}$ & $\begin{array}{l}\text { In particular in urban areas of } \\
\text { industrialized countries where space } \\
\text { is scarce }\end{array}$ \\
\hline
\end{tabular}

Note: * Enthalpy, which can be considered more or less proportional to temperature, is used to express the heat (thermal energy) content of the fluids that act as the carrier transporting heat from the deep hot rocks to the surface. According to the enthalpy criterion, geothermal resources can be divided into low-, medium- and high-enthalpy (or -temperature) resources, which gives a general indication of their potential forms of utilization. The classification is, in practice, mostly based on temperature, but standardization of the temperature limits to be applied has not yet been agreed upon in the scientific community, thus leaving some room for confusion and ambiguity. Upper temperature limits for low-enthalpy resources, as proposed by selected authors, vary between $90^{\circ} \mathrm{C}$ and $200^{\circ} \mathrm{C}$, while lower temperature limits for high-enthalpy resources are in the range of $150{ }^{\circ} \mathrm{C}$ to $250{ }^{\circ} \mathrm{C}[3]$.

\subsection{Groundwater Development and Management}

Groundwater withdrawal is by far the most widespread and most common human activity in relation to the subsurface. The volumes of groundwater abstracted annually on Earth-during 2010, some $982 \mathrm{~km}^{3}$ [4] — very significantly exceed the volumes of any other substance extracted from the subsurface. In contrast to most other subsurface activities that require highly specialized technical expertise, groundwater abstraction is extremely decentralized, since the resource and conventional withdrawal technology are within relatively easy reach of anyone who owns a piece of land. Groundwater therefore is sometimes called a social or democratic resource, but the drawback is competition and interference between uncoordinated groundwater pumpers. Scarcity of groundwater is pushing the groundwater frontier to greater depths, which requires more technological expertise and larger investments. At greater depths (beyond $600 \mathrm{~m}$ ), significant reservoirs filled with fresh groundwater (so called "deep-seated aquifers") have been identified in several regions, but often these are relatively isolated from the currently active hydrological cycle and thus are not or only poorly recharged. This makes such aquifers more suitable as a strategic resource for emergency supplies than for regular use. An additional problem related to deep-seated aquifers is that in many countries, their depth has the implication that mining law is applicable, not water law; this may also have consequences for institutional jurisdictions and mandates. 
The ubiquitous presence of groundwater causes it to be exposed and vulnerable to almost any human subsurface activity, often with negative impacts. Given the undisputed huge importance of groundwater for domestic, environmental and economic purposes, due attention should be paid to these interactions in order to prevent or minimize negative impacts.

Groundwater, in turn, can also have negative impacts on the human living environment and on human activities above or below the ground surface. The most common corrective intervention in this context is artificial drainage of excess groundwater, which has a long tradition in several countries. The reverse action-artificial replenishment of groundwater in order to enhance water availability during dry periods-is nowadays known under the term Managed Aquifer Recharge (MAR). Its worldwide implementation is still modest, but growing rapidly to enhance and secure vulnerable supplies through water banking.

\subsection{Mining}

The extraction of building materials from the subsurface and the mining of coal and of metallic and non-metallic minerals have a millennia-long history, or even date back to pre-historic times. Thousands of years ago, shafts were already constructed to reach depths of several tens of meters below the surface. The mining industry expanded particularly during the 18th and 20th centuries, and its production is still increasing. In 2013, the world's annual mining production, excluding building materials, reached approximately 9.95 billion metric tons: 1.65 for metals, 0.78 for industrial minerals and 7.52 for mineral fuels (without oil and gas) [5]. Mining generates enormous economic benefits around the world, but it also produces considerable risk to groundwater and the environment. First, because most mining operations, both underground and open-pit or surface mining, require drainage. This modifies the groundwater regime locally or sometimes even regionally, such as in the Ruhr area in Nordrhein-Westfalen (Germany) where approximately 1.2 billion cubic meters of groundwater annually is drained in order to enable open-pit mining of lignite [6]. Furthermore, mining often produces significant environmental pollution, leading to degraded groundwater and surface-water quality. These negative impacts of mining do not stop immediately when the mining operations are discontinued, but may still continue for a long time afterwards. An example is the Cornish Wheal Jane Mine in southwest England where tin was extracted from the mid-18th century until 1992. Following abandonment, the mine flooded and acid drainage water escaped into the surface drainage. The subsequent remedial works were demanded under environmental legislation at a cost of over 300 million USD [2]. Countries with weak legislation and poor enforcement capabilities related to mining are likely to be faced with a growing legacy of resource and environmental problems.

\subsection{Geo-Energy Development Based on Fluids as a Carrier of Energy}

The oil and gas sector ranks under the world's largest industries. In 2014, the world production of oil was 1659 billion barrels and that of natural gas was 201,771 billion cubic meters [7]. Oil and gas wells started to be drilled systematically during the 19th century, and currently they form the second-widest intrusion into deep underground space, after water wells. In spite of advanced technology and strict environmental regulations, all phases of hydrocarbon exploration, production and abandonment can pose a risk to groundwater resources, because of accidents that are usually the result of human errors. During drilling, loss of control over high-pressure zones can lead to a severe pressure kick or full-scale well blow-out; depending on the drilling phase, shutting in a high-pressure kick can force the reservoir fluids and gases into overlying permeable geological horizons, including aquifers. Furthermore, any deficits on the well construction related to the integrity of the casing and/or grouting can lead to problems during the operation of production-phase oil and gas wells. Holes in the casing or leakages between the casing and the well wall can allow formation fluids to migrate into overlying aquifer formations. The disposal of oil field brines by injection wells can be another source of pollution if leaks occur. 
Geothermal energy development generally is based on groundwater as a carrier of heat. On average, the temperature of groundwater increases by $30^{\circ} \mathrm{C}$ per $\mathrm{km}$ of depth, but this temperature gradient is steeper in zones of thermal anomalies, thus causing groundwater of $400{ }^{\circ} \mathrm{C}$ or more to be found at economically viable depths. Global use of geothermal energy is annually growing at a rate of $14 \%$, but it still remains an underdeveloped energy resource, compared to the vast amount of thermal energy stored within the Earth's crust. Access to this huge, low-cost, clean energy resource which could be considered infinite on a human time scale, is possible, but requires a number of technical and financial constraints to be overcome. The potential effects of geothermal energy development on groundwater vary according to the applied technology. Table 2 provides an impression, with differentiation between low-enthalpy and high-enthalpy geothermal resources.

Table 2. Potential effects of geothermal energy development on groundwater (adapted from [8]).

\begin{tabular}{|c|c|c|c|}
\hline \multirow{2}{*}{ Actions and Impacts } & \multirow{2}{*}{$\begin{array}{c}\text { Low-Enthalpy } \\
\text { Systems-HSA * }\end{array}$} & \multicolumn{2}{|c|}{ High-Enthalpy Systems-EGS ** } \\
\hline & & (a) Vapour-Dominated & (b) Liquid-Dominated \\
\hline \multicolumn{4}{|l|}{ Drilling operations: } \\
\hline Contamination by drilling fluids & Little & Moderate & Moderate \\
\hline \multicolumn{4}{|l|}{ Mass withdrawal: } \\
\hline Depletion of groundwater & No effect & Little & Moderate \\
\hline \multicolumn{4}{|l|}{ Hydrothermal eruptions: } \\
\hline Ground temperature changes & No/Little & Little & Moderate \\
\hline \multicolumn{4}{|l|}{ Waste liquid disposal: } \\
\hline Infiltration of surface disposal & Little & Little & Moderate \\
\hline Re-injection contamination of groundwater & Little & Little & Little \\
\hline
\end{tabular}

Notes: ${ }^{*}$ HSA $=$ Hot Sedimentary Aquifer $;{ }^{* *}$ EGS = Enhanced Geothermal Systems.

\subsection{Disposal and Storage of Hazardous Waste}

Apart from unintentional encroachment of solid and liquid waste into the subsurface, e.g., by leaking sewerage systems and septic tanks, or as a side effect of drilling, mining and tunneling, the subsurface is progressively being used intentionally for storing hazardous solid or liquid waste. Deep-well injection is a commonly used technique for the disposal of liquid waste or solid waste that can be reworked to a slurry. To apply this technique successfully, a permeable formation with good storage capacity is needed to receive the liquid waste, covered by an effectively impermeable rock unit to ensure that the stored waste remains permanently isolated from upper layers and the biosphere. It is clear that the risks of this technique include leakage towards other compartments of the underground and the permanent disqualification of the storage reservoir for other purposes. Typical waste products disposed by deep-well injection include waste produced in the oil and gas industry (oil field brines, cuttings, drilling mud, sulphides, mercury compounds, arsenic, cadmium), liquid waste from mining operations and all kinds of industrial and municipal liquid waste.

Also under this category comes Carbon Capture and Sequestration (CCS), which consists of storing carbon underground in order to curb accumulation of carbon dioxide in the atmosphere. It is undertaken because natural sinks of carbon (forests, oceans and soils) are considered unable to accommodate the increasing quantities of carbon dioxide emitted by humans, with consequences in terms of climate change. Major storage of $\mathrm{CO}_{2}$ is ongoing in large projects in the North Sea, in Canada and in Algeria.

Radioactive waste ranks highest within the category of hazardous waste. Its potential subsurface disposal is still controversial and unresolved, although there is wide agreement that storing nuclear waste in a geologically stable and isolated location underground is a far more promising option than dumping it in sealed barrels into the ocean, which was practiced for some time during the period 1940-1960 for low-level radioactive waste. The problem of nuclear waste lies not only in the extremely 
devastating impact of potentially released radiation on the exposed biosphere (including humans), but also in the enormous persistence of its hazardous properties. Radiation half-lives of important nuclear waste components are in the order of thousands to millions of years, which means, in practice, that a safe repository should isolate the waste from the human environment for indefinite time. Various approaches to the disposal or containment of radioactive waste can be observed. Controlled sanitary landfills are used for low-level radioactive waste, sometimes after on-site containment for a number of years as to allow decay to a safe level. Current practices in managing high-level radioactive waste are a combination of temporary storage and investigating options for permanent storage. Examples of potential sites selected and studied in detail are in volcanic rock high above the water table (e.g., Yucca Mountain, Nevada, USA), in crystalline rock (e.g., Finland, Sweden and India), in thick impermeable clay (e.g., Boom Clay Formation, Belgium) and in salt domes (e.g., Gorleben site, Germany).

A special category of radioactive pollution hazards is formed by nuclear weapons testing and nuclear power accidents. They form a significant and rather unpredictable risk to groundwater and the environment.

\subsection{Injection and Recovery}

Unlike permanent storage as discussed above, human activities also may produce the temporary storage of substances into the subsurface, to be followed by their recovery or removal. This includes, firstly, injection and recovery for mineral extraction ('solution mining'), which developed rapidly during the second half of the 19th century as a result of progress in drilling and pump technology. Until the 1950s this technique was carried out largely using water or steam, but later the use of chemical leaching solutions (lixiviants) came into vogue.

Second is the reinjection of residual geothermal fluids. It started purely as a disposal method, but has more recently been recognized as an essential and important part of reservoir management. Reinjection serves not only to maintain reservoir pressure, but also to increase energy extraction efficiency over the life of the resource.

Third is the temporal storage in shallow aquifers of the surplus heat available during low-demand periods of the year in order to recover it during periods when the energy demand is higher. A common application of such stored energy is heating of buildings during winter.

Fourth is the injection and recovery of crude oil and liquid hydrocarbons in underground caverns-natural or man-made-and in reservoirs/aquifers. The hydrocarbons are injected into the formation (in caverns or an aquifer) for storage and later pumped back out for processing and use. The underground reinjection of produced liquid hydrocarbons and natural gas can have different purposes: (i) provide the industry with short-term deliverability during peak demand and/or set aside long-term strategic reserves; (ii) increase production and prolong the life of oil-producing fields.

Fifth is 'hydraulic fracturing', a controversial technique used to increase the rate at which oil, water or natural gas can be produced from natural subterranean reservoirs, including unconventional reservoirs, such as shale rock or coal beds. Hydraulic fractures are formed by pumping a fracturing fluid under pressure into the reservoir formation. The injected fluid is typically a slurry of water, 'proppants' (usually sieved round sand) and chemical additives.

All these applications of injection and recovery present risks to aquifers and to the environment in general; effective management thus is required in order to ensure an acceptable level of risk.

\subsection{Construction into the Underground Space}

This use of subsurface space is not a new phenomenon, but it has expanded very rapidly during the last few decades. Compared to the subsurface human activities described above, underground constructions are limited to a very shallow upper zone of the subsurface.

Included are, firstly, pipelines (for water, gas and oil), sewerage systems and cables (for electricity and communication, including radio, television and Internet). In densely populated areas these are 
usually buried, at shallow depth and above the groundwater table. Leaks in sewerage systems and pipelines for oil and gas may constitute potential pollution risks for groundwater.

Tunnels and underground railways also belong to this category. If they are located below the groundwater table, which is often the case, then the groundwater regime may be significantly disturbed during construction (by artificial drainage) and compaction of compressible layers may occur. Modified hydraulic properties of these layers, in combination with constructed artificial obstacles, may, after construction, have a permanent influence on the shallow groundwater regimes. Some tunnels may form preferential entry paths for pollutants into groundwater systems.

In urban areas there is a tendency to locate new car parks underground in order to save space. In addition, plans are being developed in several countries for a much more intensive use of the shallow subsurface for buildings with commercial or public functions, especially under cities where extraction of building materials for centuries had created impressive subsurface open spaces. The potential risks of these car parks and underground buildings regarding groundwater are similar to those of tunnels and subways.

\section{Diagnostic}

\subsection{Interactions and Their Impacts}

Use of the subsurface and its resources is steadily becoming more intensive, both by the proliferation of the conventional uses and by the emergence of relatively new, non-conventional uses. From what has been presented above, it may be concluded that most of the related subsurface activities are potentially interacting and are likely to produce negative side effects, such as pollution or increased pollution risks, undesired modification of the hydrogeological regimes, or increasing competition for limited space or water. Although the interactions act in all directions, groundwater systems are particularly vulnerable and threatened by pollution and depletion. The potential impacts of these changes in state include health risks-for instance, if subsurface storage would fail to isolate hazardous substances (in particular radioactive waste or carbon dioxide) from the human environment, loss of valuable sources of water, the increasing cost of water and various types of environmental degradation (land subsidence, degradation of ecosystems, etc.). The exploitation of groundwater, on the other hand, may affect other uses of the subsurface and its resources. For instance, groundwater level declines resulting from groundwater abstraction may lead to differential subsidence of the land surface, causing damage to buried pipelines, sewerage systems and various types of subsurface constructions. Groundwater level declines, however, also open up the space required for the application of managed aquifer recharge, similar to the way exploited gas and oil fields offer repositories for storing hazardous waste.

\subsection{Expertise, Regulation and Governance in Each of the Sectors}

Technical expertise deployed in human activities in the subsurface varies from case to case, and from sector to sector. Except for some types of small-scale and simple interventions, a high level of technical expertise is generally present, especially if the activities take place at great depths and are carried out by highly specialized or large commercial companies (oil companies, mining companies, etc.). Usually the expertise allows to do more than focus on the immediate purpose of the activities (such as how to exploit a specific resource) and enables to assess the associated risks, constraints and direct impacts on other activities or interests (economic externalities) or figure out how to mitigate the latter. This technological knowledge and expertise is subject to continuous innovation.

Most countries have laws and regulations on the most important categories of human activities in the subsurface, but their quality and comprehensiveness are variable, as is the effectiveness of their implementation. These legal tools have to ensure that risks of poor concepts or designs, inadequate practices and harmful human errors are minimized, and that the industries put safety and environmental protocols duly in place and comply with these. The laws and regulations-and also 
the government agencies in charge - tend to lack coordination and tend to be fragmented over the separate subsurface use sectors.

\subsection{The Need for Coordination and Control}

The steadily more intensive multiple use of the subsurface space and subsurface resources leads undeniably to a progressively stronger interaction between the different uses, usually with negative externalities. The risks are very substantial in areas of intensive use or where hazardous projects are implemented, while any degradation of the subsurface and its resources (in particular groundwater) is virtually irreversible due to the inertia of subsurface processes. Those who produce the externalities may not be in the position or may not be motivated to avoid them, either due to lack of information and awareness, or because more priority is given to saving costs and to maximizing profits from their activities. Government agencies usually still have very fragmented involvement and mandates in the various sectors of subsurface activity. Hence, where multiple use of the subsurface is already present or is expected to come into existence in the foreseeable future, provisions should be made for coordination and control, in order to ensure sustainable use of the space and resources offered by the subsurface.

\subsection{Options and Constraints}

At first glance, it seems clear what should be aimed for: integrated management of the subsurface space and all subsurface resources. However, is this a feasible option and is it compatible with other aspirations for integration? Alternatively, should-for the time being-more modest steps towards broader governance of the subsurface domain be pursued?

To answer these questions, it is useful to have a look first at the most common constraints to achieving 'good groundwater governance', as observed in many countries [1]:

- Insufficient and/or unreliable information on the local factual situation (including geology), the predicted futures and the associated benefits, costs, risks and external impacts;

- $\quad$ Lack of awareness at all levels of what is at stake;

- Weak implementation of legal and regulatory frameworks;

- Often poor policies or even absence of policies;

- Disappointing performance of government agencies designated to play a leading role in groundwater governance, due to limitations in capacity, mandate and/or finances;

- $\quad$ Little or no effective involvement of relevant stakeholders.

Next, the interdependence between groundwater and surface water pleads strongly for adopting an integrated water resources management approach (IWRM), while other interdependencies (such as with land use, with sanitation, with energy, etc.) also call for linkages in policy, planning and management. Already in conventional groundwater management, the number and diversity of actors do form a significant challenge at the level of implementation. Adding those actors involved in all other sectors of subsurface activities will indisputably lead to much more complexity, certainly also due to the fragmentation of their goals, mandates and legal frameworks. The most likely result then will be a subsurface governance set-up too complex to function.

Therefore, an incremental approach to linking groundwater and other sectors of subsurface uses is considered more appropriate. Smart incremental steps should be designed, in terms of ambition, content and pace of implementation compatible with the local conditions. Examples of such steps include: (a) creating transparency on all subsurface activities in the area concerned, e.g., by raising awareness and public information programs, web portals and publicly accessible databases; (b) announcing to the general public all significant planned new projects related to the subsurface and permitting stakeholders to appeal against these or propose amendments; (c) introducing obligatory 'groundwater impact assessments' for new projects aimed at any use of subsurface space or subsurface 
resources. First of all, however, efforts are needed to get the subject included on the political agenda and to negotiate the allocation of the means required for implementation of planned action. To this end, awareness should be raised among politicians, key stakeholders and other important decision-makers, in order to gain political support and willingness to cooperate.

\section{Conclusions}

Multiple uses of the subsurface space and subsurface resources are rapidly encroaching in many areas around the world, especially in densely populated areas. Their interactions are becoming steadily more intensive and often create negative externalities or have the potential to do so. Groundwater and aquifers are, in particular, at risk, or have been affected already by different human subsurface activities, causing degradation of the groundwater quality or depletion of the resources. Traditionally, the different types of subsurface activities are, in most countries, carried out and governed in isolation from each other, subject to separate policies and separate legal and institutional regimes. From the point of view of groundwater governance, the need is felt to abandon this isolation and to make a linkage between groundwater and uses of the subsurface space and of other subsurface resources, in order to protect and manage the groundwater resources optimally.

Decision-makers and stakeholders involved in decision-making on the use of the subsurface need to be made aware both of the many current and potential uses of the subsurface and its resources in their area of concern, and of the geological characteristics of the area's subsurface. Furthermore, they need to have a reliable picture of the benefits, costs and risks of the individual subsurface activities (in comparison with those of non-subsurface alternatives), but they also need to understand that the different uses may interfere and produce externalities. In addition, there are two more key lessons for them to learn about the subsurface domain: First, it is difficult and expensive to explore the subsurface adequately, which results, in practice, in large uncertainties on the assumed properties and potential of the underground. Second, many processes that produce change in the subsurface are virtually irreversible, on a human time scale-or are reversible only at a very high cost.

Professionals responsible for groundwater resources management should be active and creative in finding out how to link their policies and practices to other subsurface use sectors. They should make sure that they are well-informed on all new initiatives for subsurface activities; that sufficient efforts are made to assess external risks and other external impacts; that regulations exist to promote orderly behavior; that all projects comply with these regulations; and that changes over time of the state of the subsurface and related environment are duly monitored.

Acknowledgments: The authors would like to thank all colleagues who have been contributing to the GEF funded Groundwater Governance Project (Groundwater Governance: a Framework for Action), in particular Michael Jones and Jake Burke as co-authors of Thematic Paper No. 10, and the members of the project's Steering Committee. The useful comments and suggestions of two anonymous reviewers are also gratefully acknowledged.

Conflicts of Interest: The authors declare no conflict of interest.

\section{Abbreviations}

The following abbreviations are used in this manuscript:

$\begin{array}{ll}\text { CCS } & \text { Carbon Capture and Sequestration } \\ \text { EGS } & \text { Enhanced Geothermal Systems } \\ \text { FAO } & \text { Food and Agriculture Organization of the United Nations } \\ \text { GEF } & \text { Global Environment Facility } \\ \text { HSA } & \text { Hot Sedimentary Aquifer } \\ \text { IAH } & \text { International Association of Hydrogeologists } \\ \text { IHP } & \text { International Hydrological Programme } \\ \text { IWRM } & \text { Integrated Water Resources Management } \\ \text { MAR } & \text { Managed Aquifer Recharge } \\ \text { NGO } & \text { Non-Governmental Organisation } \\ \text { UNESCO } & \text { United Nations Educational, Scientific and Cultural Organization }\end{array}$




\section{References}

1. GEF Groundwater Governance Project. Global Diagnostic on Groundwater Governance. Groundwater Governance-A Global Framework for Action. 2015. Available online: http:/ / www.groundwatergovernance. org (accessed on 1 February 2016).

2. Van der Gun, J.; Merla, A.; Jones, M.; Burke, J. Governance of the subsurface and groundwater frontier. In Groundwater Governance, A Global Framework for Action; Thematic Paper No. 10; Available online: http: //www.groundwatergovernance.org/resources/thematic-papers/en/ (accessed on 1 February 2016).

3. Dickson, M.H.; Fanelli, M. What is Geothermal Energy? International Geothermal Association. February 2004. Available online: http://www.geothermal-energy.org/what_is_geothermal_energy.html\#c317 (accessed on 9 May 2016).

4. Margat, J.; Van der Gun, J. Groundwater around the World: A Geographic Synopsis; CRC Press/Balkema: Leiden, The Netherlands, 2013.

5. Reichl, C.; Schatz, M.; Zsak, G. World Mining Data; International Organizing Committee for the World Mining Congress: Vienna, Austria, 2015.

6. Stuurman, R. Schetsen van Het Nederlands Grondwatersysteem in 2050; TNO-Report 2007-U-R0225/B; TNO: Utrecht, The Netherlands, 2007.

7. Eni Spa. World Oil and Gas Review; Eni Spa: Rome, Italy, 2015.

8. Hunt, T.M. Five Lectures on Environmental Effects of Geothermal Utilization; Report 1-2000; United Nations University—Geothermal Training Program: Reykjavik, Iceland, 2001; p. 109.

(C) 2016 by the authors; licensee MDPI, Basel, Switzerland. This article is an open access article distributed under the terms and conditions of the Creative Commons Attribution (CC-BY) license (http:/ / creativecommons.org/licenses/by/4.0/). 